\title{
THE USEFULNESS OF SPIDERS.
}

BY JOHN G. JACK, HILLSIDE, CHATEAUGUAY BASIN, $Q$.

I have often wondered why people have such a dislike for spiders, and why, instead of killing, they are not placed upon trees and plants, for they are exceedingly fond of a great many insects injurious to vegetation. I have seen them very busy devouring the interior of a chrysalis of Clisiocampa, and in winter, when out of doors, they generally hybernate under the loose bark of trees, in which case all the beetles and chrysalids in the vicinity are sure to be found destroyed, only the shells remaining. I notice that the Lady-birds (Coccinella) hybernate beside them in safety, and are never destroyed, living even within their webs. Whether this is a natural taste of the spider or an instinct I can only leave for Entomologists to determine; the fact however remains.

It is well to encourage any insect that can destroy the Clisiocampa, which is likely to cause great mischief the coming season if not destroyed in the rings. In our orchard of rooo trees, my brothers and I have, after school hours, gathered by actual count about 8000 rings, and still can take off two or three hundred in an hour's time. We are paid a cent per dozen by father, and think it a good thing. The youngest boy is only five years old, and he has frequently gathered 60 or 70 rings after school, even in the short winter afternoons. "Eternal vigilance is the price of" -apples.

\section{MISCELLANEOUS.}

Correction and Errata.--The following was received from Mr. W. H. Edwards too late for insertion in our last number : "After the mss. of my paper was sent to the printer, I discovered that I had overlooked the fact that myrina is expressly enumerated by Hübner under his coitus Argymis. Also, in reference to the same paper, the following errata: Page $\mathbf{9 3}$, lines I 4 and 17 , for 'class' read 'clan.'"

Pterophorus perisalidactylus.--On the morning of the $3^{\text {Ist }}$ October, while the thermometer was several degrees below freezing, I captured a healthy specimen of this species. Was not that very late for it?-R. VASHAN RogrRs. 